\title{
HOTOL seeks support abroad as Britain opts out of space
}

\section{London}

THE British space community was dealt a severe blow last week when the governof the space plane Hotol, the revolutionary horizontal take-off and landing space vehicle developed by British Aerospace (BAe) and Rolls Royce. They had requested $£ 12$ million over the next three years to take the project beyond the proof-of-viability phase which was successfully completed last year. That phase was funded each providing $£ 1.5$ million. The designer of Hotol's unique engine, Alan Bond, says ment refused funds for the development jointly by the government and industry,

dominate the world, says Bond. Britain would be in a position to challenge that domination only if development of Hotol went ahead bringing corresponding advances in space engineering, says Bond. BAe has now intensified attempts to find foreign partners, but progress is hindered by classification by the Ministry of Defence of Hotol's unique propulsion system. Until now the government has been very reluctant to declassify Hotol. Now that the government has said it will support efforts to find collaborators, it is considering declassification. Without that it will be very difficult, though not impos-

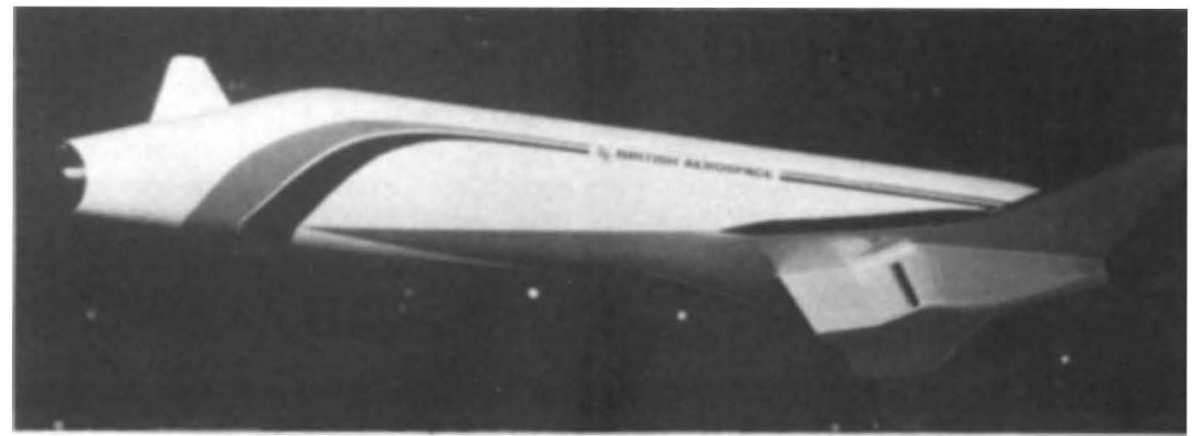

The British space plane that could make cheap space trips a reality.

there is no doubt now that the space plane is technically feasible. "It could be on the runway in 12 years" he says. And it would reduce by about one half the cost of launching satellites. At present, it costs about $£ 13$ million to put a one-tonne payload into geostationary Earth orbit; Hotol could do it for between $£ 6$ and $£ 8$ million.

The future of the spaceplane now depends on finding sponsors for its development. It was never intended that the programme should be purely national; BAe has for several years been seeking foreign partners. But the government's withdrawal seems to be a vote of no confidence in the project. "This has very seriously jeopardized the future of Hotol", says Bond. "Getting 100 per cent support from abroad will be very difficult. Countries which might be expected to collaborate are quite capable of going ahead with similar projects themselves". Britain is leading the world now, he says, but the rest of Europe is only two or three years behind. And Japan and the United States, now about 12 years behind, are making rapid advances.

If Britain misses out on Hotol, then it will quickly fall behind the international space community, says Bond. Hotol fills, at an economic price, a gap between conventional rockets and the aerospace plane of the late twenty-first century. But when increased traffic makes development costs less significant, then the expensive US propulsion system, SCRAMJET, will sible, says Bond, to elicit the necessary foreign support.

That support is vital both financially and in terms of the expertise it would bring to the project. The skills to develop the space plane no longer exist in Britain, says Bond. "At most we could expect to do 35 per cent of the work. Successive governments have run us into a state which is shameful". Bond believes that the Hotol programme brought together a team of British specialists that is world-class. That expertise is in danger of slipping away.

Though development costs may be high - between $£ 5,000$ and $£ 7,000$ million profits are not as distant as people think, says Bond. Within about 20 years, Hotol would be making a profit. And although the space plane has been designed for launching communications satellites, it can be modified to take any payload of up to eight tonnes and with further development could put astronauts into space, and even act as a commercial passengercarrying vehicle.

The government's withdrawal from Hotol depressed but did not surprise the British space community, which is already demoralized by the government's consistent refusal to increase the space budget from the current level of $£ 130$ million. And last year the head of the British National Space Centre resigned after his attempts to formulate a national policy were continually frustrated by refusal of public funding.
Christine McGourty

\section{Leaks prompt delay} in shuttle launch

\section{Washington}

LEAKS continue to plague preparations for the forthcoming launch of the space shuttle Discovery. Last weekend the National Aeronautics and Space Administration (NASA) completed a practice countdown that was to include filling the shuttle's fuel tanks with liquid hydrogen and liquid oxygen fuel. But during the fuelling procedure a leak developed in a hydrogen line leading from the fuel tanks on the launch pad to the shuttle fuel tank, and NASA abandoned plans for a complete fuelling. Earlier in the test a problem cropped up with a liquid oxygen recirculation pump, also part of the shuttle's ground support equipment.

NASA will decide later this week when to proceed with a 20 -second test firing of the shuttle's main engine. The results of that test will help determine whether engineers will attempt to repair at the launch pad a leak discovered last month in Discovery's on-orbit positioning system, or whether it will be necessary to roll the shuttle back to its hangar. If a rollback is necessary, the launch would be delayed by approximately two months. In any case, a launch before October is now problematic. Joseph Palca

\section{Concession on education bill}

\section{London}

THE UK government last week made a surprise last-minute concession to academics over the controversial clause in the education reform bill on the 'terms and conditions' which the new University Funding Council (UFC) can lay down on universities (see Nature 334, 284; 1988). Fears that the clause would allow the introduction of restrictive contract funding led to an amendment in the House of Lords which made the powers of the council less specific. But that was subsequently overturned in the House of Commons. To appease dissatisfied peers, the government quickly introduced a new clause which imposes a statutory duty on the UFC to consult appropriate bodies before imposing any 'terms and conditions'. Those bodies would be representative organizations where the whole sector is concerned, such as the Committee of Vice Chancellors and Principals (CVCP), or the governing body where an individual institution is concerned. Peers consented and the bill duly became law on $29 \mathrm{July}$, the end of the parliamentary session. Sir Mark Richmond, chairman of the CVCP, says the late clause is a "substantial extra concession". And the final form of the bill, he says, is "spectacularly improved" in respect of the universities on the original form of the bill.

Christine McGourty 